\title{
COGNITIVE STRATEGIES OF S'R MODEL USED BY HIGH PROFICIENCY LEARNERS OF THE ENGLISH DEPARTMENT, PETRA CHRISTIAN UNIVERSITY
}

\author{
Mega Sri Yunita Samalaty, Herwindy Maria Tedjaatmadja \\ English Department, Faculty of Letters, Petra Christian University, Surabaya, East Java, Indonesia \\ E-mail: adonaimega@gmail.com; windy382@petra.ac.id
}

\begin{abstract}
This is a qualitative and quantitative study on cognitive strategies of $S^{2} R$ model and specific techniques employed by high proficient learners of the English Department, Petra Christian University. The high proficient learners represented by nine final-year students who have an average of very good grade $(\geq B+)$ in all language skill courses offered by the department. The data was taken by conducting interviews to each of learners based on Oxford (2011) theory. The findings showed all types of cognitive strategies are used by the high proficient learners. The highest percentage of cognitive strategies used was going beyond the immediate data $(100 \%)$, the second highest was using senses to understand and remember $(81 \%)$, the third highest was conceptualizing broadly (78\%), then it followed by conceptualizing with details (76\%), reasoning (67\%), and activating knowledge (56\%). Moreover, there were a lot of varieties of the specific techniques employed by the participants. The most common specific techniques used were guessing, watching English speaking films, skimming, comparing English to mother tongue, reading novels and magazine, and brainstorming. In conclusion, all proficiency learners use all cognitive strategies but they might employ different techniques in their learning process.
\end{abstract}

Key words: Cognitive strategies, $S^{2} R$ model, high proficiency learners

\section{INTRODUCTION}

Language learning strategies is one several important factors which can determine how-well students learn a new foreign language or second language (Oxford, 2003). Chamot (1990), as cited in Breen (2001) mentioned that learning strategies are important for the learners because of two major reasons. Firstly, learning strategies help people; especially both teachers and learners get insight about how cognitive, social, and affective processes are involved in language learning process. Secondly, it might be useful for teachers teach less successful learners to use the strategies that are used by successful students in order to help them in improving their proficiency toward second language. Moreover, Oxford also mentioned that language learning strategies which suit learners bring positive impacts in increasing learners' language capability and self-confident (Oxford, 2011). Therefore, it can be concluded, by using effective language learning strategies in learning process, learners can improve and achieve their goal in learning the second language at a much faster rate.

Strategic Self-Regulation $\left(S^{2} R\right)$ is one model of language learning. There are three types of strategies of language learning strategies in $S^{2} R$ model which are cognitive strategies, affective strategies, and sociocultural-interactive strategies (Oxford, 2011). Cognitive strategy is chosen because it is well known as the most commonly used strategy by second language learners (Oxford, 1990). Oxford did mention, "Cognitive strategies are essentials in learning a new language", (p.43, para. 1). She also added that cognitive strategies help learners in such aspects which are constructing, transforming, and applying second language (L2) knowledge (Oxford, 2011). In S²R Model proposed by Oxford (2011), there are six cognitive strategies. Those strategies are known as "are using the senses to understand and remember, activating knowledge, reasoning, conceptualizing with details, conceptualizing broadly, and going beyond the immediate data" (p.46). In this present study, the writer focuses on finding the cognitive strategies used by high proficiency students represented by nine final year students of the English Department who had finished all courses offered and get an average very good grade $(\geq \mathrm{B}+)$ in three skills courses. The reason why the writer chooses high proficiency learners because many previous studies showed a connection between high proficiency learners and the language strategies used. A study done by Salahshour et al. (2012) proved that 
language strategies are more frequently used by high proficiency learners. In a line, another study also showed a positive relationship between learners' proficiency and strategy used does exist. "The more proficient the learners, the greater number of strategies they apply" (Gharbavi and Mousavi, 2012, p.120). Also, the writer is curious to know how cognitive strategies are implemented by high proficiency learners in Petra Christian University.

In this study, the writer aims to find out the cognitive strategies of $S^{2} R$ and the specific technique of cognitive strategies employed by high proficiency learners. Furthermore, to get information about cognitive strategies used by high proficiency learners at the English Department of Petra Christian University, the writer conducts interview to each of the students. The interview questions adopted from cognitive strategies statements proposed by Oxford (2011) which depicts the whole ideas about cognitive strategies in $\mathrm{S}^{2} \mathrm{R}$.

In answering the research question, the writer used Oxford theory. Oxford (2011) proposed six cognitive strategies as can be seen in figure 1 below.

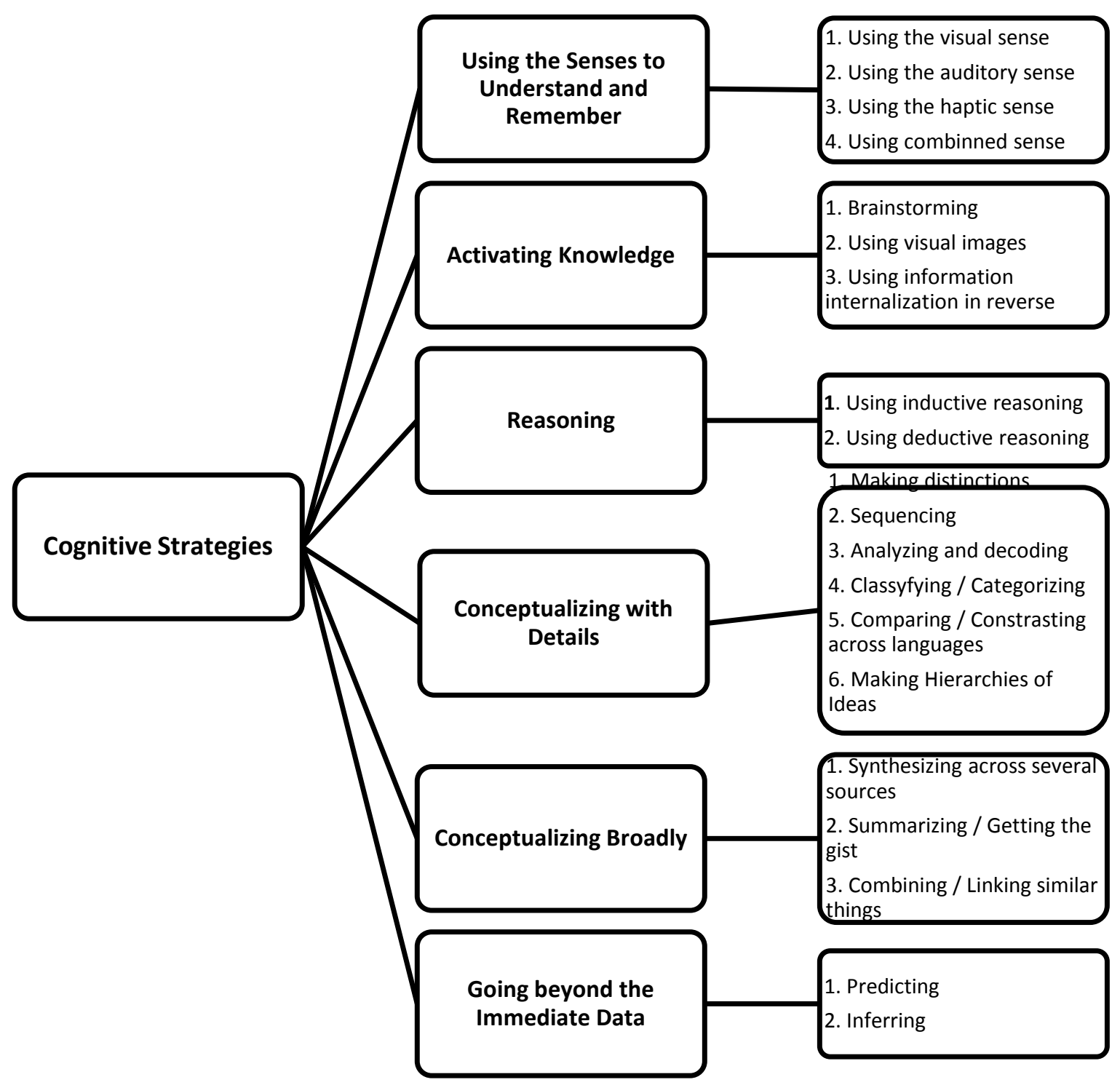

Figure 1 Types of cognitive strategies and its basic function proposed by Oxford (2011)

Figure 1 is not provided by Oxford in her book, it is made by the writer to help her to have clear insight and understanding toward Oxford's cognitive strategies theory. The following paragraphs shows a brief explanation of each strategy as mentioned above.

The first strategy is using the senses to understand and remember (Oxford, 2011, p.46). This strategy emphasizes on how senses are involved and helping students in second language learning 
process. Besides, it has four basic functions which are using visual senses, using auditory senses, using haptic or kinesthetic senses, and the combination between using visual, auditory and haptic senses at the same time or known as combined senses (Oxford, 2011).

The second strategy is activating knowledge consists of three basic functions which are brainstorming, using visual images to activate knowledge, and using information-internalization in reverse. This strategy deals with how learners are able to "re-call" their knowledge it is needed (Oxford, 2011).

The third strategy is reasoning which consists of two basic functions which are deductive and inductive reasoning. Deductive reasoning refers to a condition where learners tend to use general rules then implement it to the target language that they learn (Oxford, 1990). Meanwhile, inductive reasoning is the opposite of deductive reasoning.

The fourth strategy is conceptualizing with details which has six basic functions, making distinctions, sequencing, analyzing and decoding, classifying or categorizing, comparing or contrasting across languages, and making hierarchies of ideas. Basically, this strategy deals with how going into details could also help learner in learning English.

The fifth strategy is conceptualizing broadly consists of synthesizing across several sources, summarizing or getting the gist, and combining or linking similar things. Basically, the idea of this strategy is talking about how broad conceptualizing help learners in getting a better understanding toward language that they learn.

The last strategy is going beyond the immediate data. It consist of predicting and inferring meaning that content and clues can help learners in understanding certain texts, words, or sentences.

\section{METHODS}

In this study, the writer used mixed methods where the quantitative and qualitative principles were combined at the data analysis stage by quantifying the data.

The writer conducted a semi-structured interview, in which there were 20 questions given and each of the questions reflected six cognitive strategies as well as the basic function that it had. For example, the first part of the questions reflects the first cognitive strategy which is using senses to understand and remember. In this part, there are four questions and each of the question represents each basic of using the visual to understand and remember strategy; the first question reflects using visual sense to understand and remember, the second question reflects using auditory sense to understand and remember, the third question portrays using haptic or kinesthetic sense, and the last question of this part shows the use of combined senses to understand and remember. Eight learners were interviewed in Indonesian while English was used to interview one non-Indonesian respondent.

The writer also gave code, for example, $I$ stands for the writer as the interviewer. Meanwhile, the codes for the interviewees are, A (first learner), B (second learner), C (third learner), and so forth. Besides, the writer added the number after the alphabet as an indicator of replies or answers order. For instance, $A_{l}$ means the first reply or answer of student A. Then, the writer classified the interview questions and answers into its basic functions of cognitive strategies and wrote down the abbreviation of each basic function. For instance, utterance $\mathrm{H} 1$ - H6 and utterance I1 - I6 portrayed the first basic function of the first cognitive strategies which is UTVS. Also, the writer drew a parenthesis and wrote down abbreviations of cognitive strategies as a sign which signified every cognitive strategy.

Finally, after getting all the interview result, the writer looked at all the data and identified each one to the right cognitive strategy in the table. This was done by putting a tick on a table and counting the total number of the each basic function used.

Furthermore, the writer used two types of formulas. The first formula is used to find out the percentage basic functions used and the other one is used to find out the average of each cognitive strategies used.

$1^{\text {st }}$ Formula

$$
X=\frac{a}{b} \times 100 \%
$$

Notes:

$\mathrm{X}=$ percentage of basic functions

$a=$ the sum of the numbers in each set basic function 
$b=$ the number of participants

$2^{\text {nd }}$ Formula

$$
A=\frac{\operatorname{sum}(x+y+z)}{S} \times 100 \%
$$

Notes:

A $\quad=$ average

Sum $\mathrm{X}-\mathrm{Z} \quad=$ the total of percentage of each basic function on each strategy

$\mathrm{S} \quad \quad=$ the total of basic function on each strategy

\section{ANALYSIS AND FINDINGS}

Table 1.1 Finding Table of Each Basic Function and Overall Cognitive Strategies Used

\begin{tabular}{|c|c|c|c|c|}
\hline No & $\begin{array}{l}\text { Cognitive } \\
\text { Strategy }\end{array}$ & Basic Function & Score & $\begin{array}{l}\text { Average of } \\
\text { Percentage }\end{array}$ \\
\hline \multirow{2}{*}{1.} & \multirow{2}{*}{ GBTID } & PRED & $100 \%$ & \multirow[b]{2}{*}{$100 \%$} \\
\hline & & INF & $100 \%$ & \\
\hline \multirow{4}{*}{2.} & \multirow{4}{*}{ UTSTUAR } & UTVS & $100 \%$ & \multirow[b]{4}{*}{$81 \%$} \\
\hline & & UTCS & $100 \%$ & \\
\hline & & UTAS & $78 \%$ & \\
\hline & & UTHS & $44 \%$ & \\
\hline \multirow{3}{*}{3} & \multirow{3}{*}{$\mathrm{CB}$} & SUM/GTG & $100 \%$ & \multirow[b]{3}{*}{$78 \%$} \\
\hline & & SASS & $67 \%$ & \\
\hline & & COMB/LST & $67 \%$ & \\
\hline \multirow{6}{*}{4} & \multirow{6}{*}{ CWD } & SEQ & $100 \%$ & \multirow[b]{6}{*}{$76 \%$} \\
\hline & & CL/CA & $100 \%$ & \\
\hline & & MHOI & $89 \%$ & \\
\hline & & AAD & $78 \%$ & \\
\hline & & $\mathrm{COM} / \mathrm{CON}$ & $67 \%$ & \\
\hline & & MD & $22 \%$ & \\
\hline \multirow{2}{*}{5} & \multirow{2}{*}{$\mathrm{RE}$} & UDR & $100 \%$ & \multirow[b]{2}{*}{$67 \%$} \\
\hline & & UIR & $33 \%$ & \\
\hline \multirow{3}{*}{6} & \multirow{3}{*}{$\mathrm{AK}$} & $\mathrm{BR}$ & $100 \%$ & \multirow[b]{3}{*}{$56 \%$} \\
\hline & & UIIR & $67 \%$ & \\
\hline & & UVI & $0 \%$ & \\
\hline
\end{tabular}

Based on the writer's analysis, all cognitive strategies are used by high proficiency learners at the English Department of Petra Christian University. The first highest cognitive strategy found was going beyond the immediate data. All learners mentioned that they employed going beyond the immediate data through its basic functions, making prediction and inference. Most of participant learners mentioned that by doing prediction and inference, it helped them to answer the listening or questions or tasks in a short time. This is in accordance with the Hosenfeld's previous study (1977, as cited in Oxford, 2011 (Oxford R. L., 2011)) stating that guessing the meaning or predicting what will come next is used by successful learners.

Secondly, using senses to understand and remember found as the second highest strategy used. The writer assumed that this type of cognitive strategy might have close relationship with learners' learning style. Nunan (1991, as cited in Maria, 2004) said that learning style is learners' preferred or personal style in learning. Besides, Gilakjani (2012) stated that someone who knows his/her learning style and engaging it in learning process will learn easily and fast and will be 
sucessful. Therefore, the writer concluded that using senses in learning process might help learners in learning language more effective and become a succesful learners.

Thirdly, conceptualizing broadly was found as the third highest cognitive strategy which used by $78 \%$ of total of the participants. This strategy has 3 basic functions which have a significant contribution to help learners. The first basic function is synthesizing across several sources. It helps students to understand materials if they are not satisfied with what they get from courses books. The second basic function which is getting the gist has proven to have an important role since it gives students chance to understand a passage deeply even though learners are not in a classroom environment (Pappa, 2015). Lastly, combining phrases of English and the learners' mother tongue is also preferred. In fact, Meyer (2008) stated that "permitting the use of some words from the students first language may keep the class moving forward, by allowing the students to express themselves which making class more fun and helping them to anchor new L2 vocabulary to L1 concepts".

Fourthly, conceptualizing with details used by $76 \%$ of total learners. This strategy consist of six basic functions which are making distinction, sequencing, analyzing and coding, classifying/categorizing, comparing/contrasting across languages, and making hierarchies of ideas. Oxford (2011) claimed that high proficient learners know when to translate accordingly, using word by word or context translation or in other words they know how to make distinctions, which is reflected in the result of this study. In addition, according to Roberts (2009), other function basic function in this strategy, sequencing is used by learners in all levels since it helps them in making correct ideas about a passage. Analyzing and decoding are also used by successful learners who are analytic, detail-oriented, and left-brain dominant (Leaver, 2003, as cited in Oxford, 2011). Classyfying and categorizing is also used by the participants as Chamot (1984, in Schmitt, 2007) mentioned that "proficient learners favor grouping strategies more than begineers did". Moreover, comparing/contrasting is preferred by English learners as one detail they highlight. This might happen because learners' L1 and L2 have general advantage as they might have some similar concepts and structures (Meyer, 2008). The last mentioned basic function is making hierarchies of ideas. As many participants mentioned that they do make hierarchies of ideas mostly when they are in their writing lesson. This is expected to happen since they are English language learners, and English academic and professional writing prefers hierarchical ideas in advance before details are interpreted (Sanyal, 2013).

Fifthly, reasoning is one of the strategies which is used by $67 \%$ of total learners. This cognitive strategy has two basic functions which are using inductive reasoning and using deductive reasoning. Shaffer (1989 in Birmingham, 2012) claimed that "when grammar is presented deductively it will be easier for learners to understand the written / spoken form of languages as learners aware of the rules". This could be the reason this particular function is being used by the participants, at least when they just started learning English.

Lastly, activating knowledge which used by $56 \%$ of total learners. This cognitive strategy has three basic functions which are brainstorming, using visual images, and using information internalization in reverse. From these three basic functions, the most used basic function is brainstorming. Brainstorming is chosen more than the other two could be because brainstorming helps them a lot in reading, listening, and writing tasks. This is in accordance with what Rhalmi (2010) said, "Brainstorming increases the richness of ideas explored, particularly before reading, listening and writing activities". The participants also used information internalization in reverse. Cohen and Aphek (1980) found that students frequently use the association that s/he used originally when they learn that certain words, and that they have the best performance using this.

Table 1.2 Specific Techniques Employed by the Participants

\begin{tabular}{|l|l|l|}
\hline No & Cognitive Strategy & Specific Technique Used \\
\hline
\end{tabular}




\begin{tabular}{|c|c|c|}
\hline 1 & $\begin{array}{l}\text { Using Sense to Understand and } \\
\text { remember }\end{array}$ & $\begin{array}{l}\text {-Watching talk show videos (e.g. Ellen } \\
\text { DeGeneres, Oprah, and Jimmy Fallon } \\
\text {-Watching anime using English sub title } \\
\text {-Watching English speaking films } \\
\text {-Watching and music videos } \\
\text {-Using picture books } \\
\text {-Reading novels (e.g. Harry Potter, Winter } \\
\text { Sonata) } \\
\text {-Using grammar graphic } \\
\text {-Using figure or table } \\
\text {-Listening to talk show } \\
\text {-Listening to songs (e.g. popular songs, rnb } \\
\text { songs) } \\
\text {-Write down new words/vocabulary in } \\
\text { notes or next to the words }\end{array}$ \\
\hline 2 & Activating Knowledge & $\begin{array}{l}\text {-Brainstorming through writing down ideas } \\
\text {-Retreiving knowledge }\end{array}$ \\
\hline 3 & Reasoning & $\begin{array}{l}\text {-Doing repetitive grammar exercise on the } \\
\text { taught grammar lesson } \\
\text {-Working on grammar exercises or } \\
\text { homework given } \\
\text {-Reading newspaper } \\
\text {-Reading novels }\end{array}$ \\
\hline 4 & Conceptualizing with details & $\begin{array}{l}\text {-Writing paragraph or essay ideas } \\
\text { accordingly } \\
\text {-Break sentences into by its part of speech } \\
\text {-Comparing English to mother tongue } \\
\text {-Using signs by the most important } \\
\text { information (e.g. star, highlight, } \\
\text { underlined, exclamation) }\end{array}$ \\
\hline 5 & Conceptualizing broadly & $\begin{array}{l}\text {-Browsing internet to read related materials } \\
\text { before class or test } \\
\text {-Skimming } \\
\text {-Combining English and mother tounge } \\
\text { pharases in writing } \\
\text {-Making context distinction in translation }\end{array}$ \\
\hline 6 & $\begin{array}{l}\text { Going beyond the Immediate } \\
\text { Data }\end{array}$ & $\begin{array}{l}\text {-Guessing } \\
\text {-Using context and clues to understand }\end{array}$ \\
\hline
\end{tabular}

Table 1.2 shows the specific techniques employed by those proficiency learners.

One of the specific techniques found in using the senses to understand and remember was watching English speaking films. Watching English speaking films can help learners in learning English as mentioned by one representative learner below:

\section{Excerpt 1}

$\mathrm{E}_{3}:$ Aku pake film sih. Jadi filmnya itu kan bahasa inggris kadang aku ganti subtitlenya dari bahasa indonesia ke bahasa inggris jadi supaya bisa liat juga kata yang digunakan sama pronunciationnya kayak apa. Terus, itu bantu listening banget (I used film. The film was using English. Sometimes I changed the subtitle from Indonesian language to English so I can see words that are being used and how they are pronounced. Besides, it really helped in listening)

From the excerpt above, the writer concluded, through watching English speaking films, it helped learner E in learning English especially in listening and pronunciation. 
In activating knowledge, brainstorming is one of the specific techniques used by high proficiency learners. Brainstorming can help learners to deliver their ideas clearly and in the right order, as mentioned by learner B below:

Extract 2

$\mathrm{B}_{28}$ : Aku juga sering buat individual brainstorming. Jadi brainstormingku itu biasanya aku nyatet-nyatet dulu, nyatet-nyatet semua apa yang ada dipikiranku terus nanti aku seleksi sendiri mana yang paling masuk akal atau mana yang paling appealing lah buat di presentasikan kayak gitu. (I usually do individual brainstorming as well. In doing brainstorming, I start from writing, writing down every single thing that I have in my mind then selecting the reasonable or the most appealing ideas to be presented)

The excerpt above shows how brainstorming ideas help learner B to select or find out the most reasonable ideas to be presented.

In reasoning, one of the specific techniques which also help learner in learning English is reading novels as mentioned by the representative learner below:

Extract 3

$\mathrm{G}_{33}$ : ..... Contoh belajar grammar dari novel yang aku masih ingat itu, ada novel gitu yang dia pake $1^{\text {st }}$ point of view tapi dia pake past tense tapi novel lain ada yang pakai present tense. Jadi kita bisa liat dia jelasin suatu event itu gimana pakai present atau past tense gitu (.... I prefer some novel genres such as romance, fantasy, preferably drama. I remember an example of how I learn grammar through reading novel. There was a novel which used the $1^{\text {st }}$ point of view but using past tense yet there was also other novel which used present tense. So, we can see how an event is explained by using present or past tense)

Excerpt 3 shows how reasoning which implemented through reading novels helped Learner $\mathrm{G}$ in her learning process. By reading novel learner $\mathrm{G}$ could out how present tense and past tense were used to explain an event. Therefore, the writer concluded that reading novels can be used as both media and technique in learning English.

In conceptualizing with details, using certain signs to signified important information was the common specific used by learners. It was indicated, by signs play a role as a reminder for learners as mentioned by learner below:

Extract 4

E55: Oh iya tapi biasanya itu tak garis bawah atau bintang. Kalau ada kata-kata ato info penting, iya-iya aku stabilo (Yes, I usually make an underline or draw a star. I usually use highlighter if there are words or important information)

$\mathrm{E}_{56}$ : Karena jadi kalau di baca-baca lagi tuh jadi kan kalo di stabilo jadi bisa ingat kalo penting (If I re-read again and see the highlight I'll remember that it's important point)

Excerpt 4 shows how conceptualizing with details which implemented through make an underline or draw a star help learner $\mathrm{E}$ in memorizing important things that she learned.

In conceptualizing broadly, skimming was one of the specific techniques used by high proficiency learners as mentioned by a representative learner below:

Extract 5

$\mathrm{B}_{87}$ : Lek aku gak salah inget ya dulu pas written satu pas semester awal-awal itu kita diajarin soal teknik membaca gitu ya, scanning sama skimming. Nah aku pakai teknik itu, skimming ya kalo gak salah, jadi gak tak baca word by word tapi kayak nyari ini yang mana topic sentencenya terus aku liat soalnya juga jadi sekalian njawab gitu (If I am not mistaken in the beginning of semester during Written 1, we were taught the reading techniques, scanning and skimming. I use that technique, skimming, by which I do not read word by word but I try to find out the topic sentences then I look on the (comprehension) questions while answering the questions)

Excerpt 5 shows how conceptualizing broadly was implemented through skimming. As mentioned by learner $\mathrm{B}$, she used skimming while dealing with reading passage. It was indicated that skimming was one of reading strategies which taught by her teacher in written class and she started to apply it.

In going beyond the immediate data, one of the specific techniques found was guessing as mentioned by Learner F below: 


\section{Extract 6}

$\mathrm{F}_{56}$ : Iya, jadi punya kayak klu kira-kira orangnya bakal ngomong kayak apa liat dari kontennya ato jawabannya gitu. Di ept tes juga pernah, karna ada way timenya juga jadi bisa nebak speakernya bakal ngomong apa (Yes, so it's like I have a clue about what the speaker will say by looking at the content or answers. I also did it in EPT test, because there is a way time so I can guess what the speaker is going to say)

$\mathrm{F}_{57}$ : Biar bisa make sense terus sama bisa nebak jawaban juga lebih cepat (In order to make sense of it and able to guess the answer in a short time)

Learner $\mathrm{F}$ also shared the same experience and thought with learner $\mathrm{H}$. In utterance $\mathrm{F}_{56}$, learner F mentioned she also did prediction in EPT (English Proficiency Test) and it was done through guessing. She mentioned clearly that clues, content or answer were things that help her in doing guessing. In addition, waiting time in listening section was one factor helped her in guessing what will be said by the speaker. So, the writer concluded that the specific technique used by learner $\mathrm{F}$ in predicting is guessing, specifically, guessing through clues, content, and answer.

\section{CONCLUSION}

From the data analysis of this study, the writer found that all cognitive strategies were used by learners yet the percentage of using it was different. The first highest cognitive strategy used was going beyond the immediate data $(100 \%)$. The second highest percentage was using the senses to understand and remember $(81 \%)$. The third highest percentage was conceptualizing broadly (78\%). Then it followed by conceptualizing with details $(76 \%)$, reasoning $(67 \%)$, and the last one was activating knowledge (56\%).

Also, from her analysis the writer found out that there were a lot of varieties of the specific techniques of cognitive employed by learners such as guessing which represents going beyond the immediate data, watching English Films which represents using the senses to understand and remember, skimming which represents conceptualizing broadly, writing paragraphs or essay ideas accordingly which represents conceptualizing with details, doing the repetitive grammar exercises which represents reasoning and brainstorming which represents activating knowledge.

To conclude, the high proficient learners use all the cognitive strategies and this strategy contributed to their process of learning English. Yet, high proficient learners might employed different specific techniques in their learning English process as Griffiths (2013) "successful learners are able to choose from a repertoire of strategies those which best suit their own goals, situations, and individual characteristics".

\section{REFERENCES}

Birmingham, U. o. (2012). Introduction of language. (Unpublished essay).

Breen, M. (2001). Learner contributions to language learning:new directions in research. New York: Pearson Education Limited.

Cohen, A. D., \& Aphek, E. (1980). Retention of second-language vocabulary over time: Investigating the role of mnemonic associations . System, 221-235.

Gharbavi, A., \& Mousavi, S. (2012). Do language proficiency levels correspond to language learning strategy adoption? English Language Teaching Journal, V, 118.

Gilakjani, A., \& Ahmadi, S. (2011). The effect of visual, auditory and kinaesthetic learning style in language teaching. $V$. Retrieved November $10^{\text {th }}, 2016$ from http://www.ipedr.com/vol5/no2/104-H10249.pdf

Griffith, C. (2013). Second Language Acquisition : Strategy Factor in Successful Language Learning. Clevedon, GB: Multilingual Matters.

Maria, H. (2004). The Language Learning Strategies Used by the Higher Proficiency Learners of the 1990 and 2000 Batches of the English Department. (NO:1239/ING/2004). Unpublished Undergraduate Thesis. Petra Christian University, Surabaya 
Meyer, H. (2008). The Pedagogical Implications of L1 User in L2 CLassroom. Retrieved November $16^{\text {th }}$, 2016 from www.kyoai.ac.jp/college/ronshuo/no_008/meyer1.pdf

Oxford, R. (2003). Language learning styles and strategies: an overview. Retrieved November $2^{\text {nd }}$, 2016 from http://web.ntpu.edu.tw/ language/workshop/read2.pdf

Oxford, R. L. (2011). Teaching and researching language learning strategies. New York: Routledge.

Pappa, E. (2015, March 24). How to help English learners read more quickly. Retrieved November $13^{\text {th }}, 2016$ from BRITISH COUNCIL: https://www.britishcouncil.org/voices-magazine/howhelp-english-learners-read-more-quickly

Roberts, L. (2009, July 13). Lesson Planet. Retrieved November $20^{\text {th }}, 2016$ from www.lessonplanet.com: https://www.lessonplanet.com/article/reading-using-sequence-as-areading-strategy

Sanyal, B. (2013). Breaking This Boundaries: A One-Word Approach to Planning Education. New York: Springer Science \& Business Media.

Schmitt, N. (1997). Vocabulary learning strategies. In N. Schmitt, \& M. McCarthy (Eds.), Vocabulary: Description, Acquisition, and Pedagogy (pp. 199-227). Cambridge: Cambridge University Press. 